\title{
Solitary Osteochondroma
}

National Cancer Institute

\section{Source}

National Cancer Institute. Solitary Osteochondroma. NCI Thesaurus. Code C53455.

An osteochondroma affecting a single anatomical site. 